\title{
Edukasi Terapi Farmakologi Covid-19 Pada Pasien Tanpa Gejala dan Gejala Ringan yang Melakukan Isolasi Mandiri di Desa Cimekar
}

ED. Yunisa Mega Pasha ${ }^{1}$

${ }^{1}$ Universitas Bhakti Kencana Bandung

E-mail : edyunisa.megapasha@bku.ac.id

\section{Suherdin²}

${ }^{2}$ Universitas Bhakti Kencana Bandung

E-mail : suherdin@bku.ac.id

Dhien Novita Sani ${ }^{3}$

${ }^{3}$ Universitas Bhakti Kencana Bandung

E-mail : dhien.sani@bku.ac.id

\author{
Putri Aliza Dwi RA ${ }^{4}$ \\ ${ }^{4}$ Universitas Bhakti Kencana Bandung \\ E-mail : ak118137@bku.ac.id
}

\section{Adhaniar shafira elsafat ${ }^{5}$}

${ }^{5}$ Universitas Bhakti Kencana Bandung

E-mail : 191f04012@bku.ac.id

\section{Novianti Nurfitri ${ }^{6}$}

${ }^{6}$ Universitas Bhakti Kencana Bandung

E-mail : ak118127@bku.ac.id

\section{Article History:}

Received: 2021-11-03

Revised: 2021-12-17

Accepted:2022-01-13
Abstract: The emergence of Coronavirus Disease 2019 (Covid-19) first occurred in Wuhan, China in December 2019, this virus was caused by Severe Acute Respiratory Syndrome Coronavirus 2 (SARS-CoV-2). The increase in the number of Covid-19 cases can be seen from the example of a village in Bandung City, namely Cimekar Village which has recorded 50 cases with the impact of 1 person dying, 1 person being treated, and 48 people doing self-help. isolation (ISOMAN). This study focuses on aspects of public knowledge on how to handle Covid-19 with pharmacological therapy. The writing method that the author uses is a comparative study where the author gives a pretest, then delivers a webinar with the title Covid-19 Pharmacological Therapy to Isoman patients, without symptoms and 
mild symptoms. After that, we did a posttest. Activities are documented and published through mass media, social media, and journal articles. The results of the webinar and evaluation of the written test increase knowledge and understanding of the application of Covid-19 pharmacological therapy. The average value for the pretest is 7.97 and the average value for the posttest is 8.06 from the results of the average pair experiencing a change in value or an increase in value while the posttest average value is 8.06. Counseling with the application of Covid-19 pharmacological therapy in Cimekar Village can increase knowledge on how to apply therapy to Covid-19 patients with mild and asymptomatic symptoms, this is expected to be a driving force for changes in community behavior in handling Covid-19.

\section{Riwayat Artikel :}

Diajukan: 13-11-2021

Diperbaiki: 17-12-2021

Diterima: 13-01-2022
Abstrak: Kemunculan Coronavirus Disease 2019 (Covid-19) pertama kali terjadi di Wuhan, China pada Desember 2019, virus ini disebabkan oleh Severe Acute Respiratory Syndrome Coronavirus 2 (SARSCoV-2). Peningkatan jumlah kasus Covid-19 dapat dilihat dari contoh sebuah desa di Kota Bandung yaitu Desa Cimekar yang telah mencatat 50 kasus dengan dampak 1 orang meninggal dunia, 1 orang dirawat, dan 48 orang melakukan swadaya. Tolong. isolasi (ISOMAN). Penelitian ini berfokus pada aspek pengetahuan masyarakat tentang cara penanganan Covid-19 dengan terapi farmakologis. Metode penulisan yang penulis gunakan adalah studi banding dimana penulis memberikan pretest, 
Kata kunci:

JURNAL ASTA

Abdi Masyarakat Kita

Vol. 02 No. 01, Januari 2022

kemudian menyampaikan webinar dengan

judul Terapi Farmakologi Covid-19 kepada pasien Isoman, tanpa gejala dan gejala

ringan. Setelah itu, kami melakukan posttest. Kegiatan didokumentasikan dan dipublikasikan melalui media massa, media sosial, dan artikel jurnal. Hasil webinar dan evaluasi tes tertulis menambah pengetahuan dan pemahaman penerapan terapi farmakologi Covid-19. Nilai rata-rata untuk pretest adalah 7,97 dan nilai rata-rata untuk posttest adalah 8,06 dari hasil ratarata pasangan mengalami perubahan nilai atau kenaikan nilai sedangkan nilai rata-rata posttest adalah 8,06. Penyuluhan dengan penerapan terapi farmakologi Covid-19 di Desa Cimekar dapat menambah pengetahuan tentang cara penerapan terapi pada pasien Covid-19 dengan gejala ringan dan tanpa gejala, hal ini diharapkan dapat menjadi motor penggerak perubahan perilaku masyarakat dalam penanganan

Covid-19, SARS-Cov-2, Terapi Farmakologi. Covid-19.

\section{Pendahuluan}

Coronavirus adalah virus RNA yang memiliki kapsul dan tidak memiliki segmen. Coronavirus adalah virus golongan ordo Nidovirales, family Coronaviridae. Karakteristik dari Coronavirus adalah virus ini memiliki bentuk bulat hingga elips yang diselubungi kapsul, tidak bersegmen dan memiliki genom RNA yang panjang (Suhandi et al., 2020).

Asal muasal Coronavirus Disease 2019 (Covid-19) ini terjadi pertama kali di Wuhan, China pada bulan Desember 2019, virus ini disebabkan oleh virus Severe Acute Respiratory Syndrome Coronavirus 2 (SARS-CoV-2). Kecepatan menyebarnya virus dapat menyebabkan lumpuhnya ekonomi dan kesehatan di berbagai negara. 
Gejala utama yang dirasakan oleh orang yang terinfeksi oleh Covid-19 adalah munculnya demam dengan suhu tubuh lebih dari $38^{\circ} \mathrm{C}$, batuk kering dan sesak nafas. Gejala lainnya yang dapat timbul diantaranya nafas terasa berat, kelelahan, mialgia, diare dan gejala pernapasan yang mirip dengan pneumonia. Gejala ini dapat dirasakan mulai satu minggu setelah terpapar oleh virus dan gejala dapat memburuk secara cepat dan progresif pada kasus berat. Namun ada juga pasien yang hanya mengalami gejala ringan yang tidak mengalami demam (WHO, 2020).

Pandemi Covid-19 di Indonesia merupakan bagian dari pandemi penyakit Covid-19 yang sedang berlangsung di seluruh dunia yang disebabkan oleh sindrom pernapasan akut parah SARS-CoV-2. Virus itu dipastikan menyebar ke Indonesia pada 2 Maret 2020, setelah seorang instruktur tari dan ibunya dinyatakan positif terkena virus. Keduanya terinfeksi dari warga negara Jepang (Ratcliffe, 2020). Satu-satunya terapi pencegahan yang aman adalah dengan menggunakan perkembangan obat baru atau menggunakan obat yang sudah ada dan jelas walaupun hasilnya belum terlalu efektif (Rusdi, 2021).

Sampai pada tanggal 23 Agustus 2021 kasus Covid-19 didunia terdeteksi 212 juta kasus dan 4,43 juta kasus meninggal dunia. Kasus Covid-19 di Indonesia mencapai 3,98 juta kasus dan 126 ribu meninggal dunia, untuk di jawa barat pada tanggal 22 Agustus 2021 kasus Covid19 mencapai 12.408 jiwa dan 1.030 jiwa meninggal dunia, untuk kota bandung 23 Agustus 2021 kasus Covid-19 mencapai 1,877 jiwa dan 1.377 jiwa meninggal dunia (Worldometers, 2021). Kasus di Desa Cimekar sendiri saat ini yang positif Covid-19 mencapai 50 orang. 1 orang meninggal dunia, 48 melakukan isolasi mandiri, dan 1 orang dirawat.

Oleh karena itu perlu dilakukan sosialisasi melalui penyuluhan terhadap masyarakat khususnya masyarakat yang sedang melakukan isolasi mandiri. Hal ini menjadi penting karena masyarakat yang melakukan isolasi mandiri tidak dipantau secara terus menerus oleh petugas kesehatan. Terdapat kejadian dimana pasien yang melakuka isolasi mandiri ditemukan meninggal karena salah mengkonsumsi obat bahkan menolak menkonsumsi obat (Davina, 2021).

Pada kondisi dimana masyarakat menolah mengkonsumsi obat maka perlu upaya untuk memeberikan edukasi, salah satunya melalui penyuluhan tentang terapi farmakologi. 
Terkait penerapan terapi farmakologi untuk mengurangi terjangkitnya gejala yang lebih parah. Penerapan terapi farmakologi yang diberikan pada pasien dengan status isolasi mandiri (isoman) bisa dengan meminum vitamin C, vitamin D, Vitamin E, Zink, obat - obatan jika bergejala ringan (tanpa sesak)/ Obat rutin sesuai kondisi penyerta (Rusdi, 2021).

Desa Cimekar merupakan Desa dari Kecamatan Cileunyi Kabupaten Bandung yang memiliki populasi masyarakat yang lumayan padat. Tidak mungkin ketua Desa tersebut tidak memiliki pasien yang terjangkit virus Covid-19. Tercatat jumlah warga yang terpapar virus sampai 50 orang yang dimana, 1 orang meninggal dunia, 48 melakukan isolasi mandiri, dan 1 orang dirawat. Dilihat dari data di atas dapat di simpulkan bahwa warga Desa Cimekar paling banyak itu terpapar virus Covid-19 dengan pasien isoman. Oleh karena itu untuk menangani kasus tersebut diperlukannya penyuluhan penerapan terapi farmakologi kepada warga Desa Cimekar yang sedang melakukan isolasi mandiri.

Tujuan dari kegiatan ini adalah meningkatkan pengetahuan dan pemahaman warga Desa Cimekar yang sedang melakukan isolasi mandiri untuk penanganan menerapkan terapi farmakologi sehingga mampu mengurangi jumlah kasus Covid-19.

\section{Metode}

Metode pelaksanaan dalam kegiatan ini meliputi:

\section{Keterlibatan Pihak lain dalam Pelaksanaan Program}

Keterlibatan pihak lain dalam pelaksanaan program ini adalah melibatkan atau mitra yaitu Pengurus satgas Covid-19 Desa Cimekar, Kecamatan Cileunyi yang meliputi kunjungan salah satu anggota Kuliah Kerja Nyata (KKN) kelompok 31 dan survei lokasi, mengadakan kesepakatan mitra yang dibantu oleh satgas Covid-19 setempat dilaksanakan pada tanggal 2 Agustus 2021.

\section{Tahapan Pelaksanaan Kegiatan}

Penyelenggaraan penyuluhan secara daring ini akan dilaksanakan kepada masyarakat Desa Cimekar, Kecamatan Cileunyi, Kabupaten Bandung dengan menggunakan aplikasi zoom Tema penyuluhan yaitu "Terapi Farmakologi Pada Pasien Covid-19 Orang Tanpa Gejala (OTG), Gejala Ringan dan Isoman" sehingga dengan adanya penyuluhan ini 
masyarakat Desa Cimekar dapat mengetahui informasi pentingnya Obat-obatan khususnya vitamin untuk awal pencegahan efektif Virus Covid-19 dengan tahapan kegiatan webinar sebagai berikut :

a) Mencari mitra

- $\quad$ Mencari mitra yang sesuai dengan sasaran kriteria.

- Melakukan identifikasi permasalahan mitra.

b) Perizinan Kesbangpol

c) Persiapan Informasi dan Webinar

- Menyiapkan informasi dan acara webinar sesuai dengan kegiatan yang akan dilaksanakan.

d) Persetujuan Resmi Mitra

- Membawa surat persetujuan ke puskesmas lalu ditandatangani oleh pihak dari puskesmas

- Membawa surat persetujuan dari satgas Desa Cimekar

e) Penyesuaian jadwal penyuluhan secara daring dengan mitra.

f) Pelaksanaan webinar, dimana materi yang disampaikan sesuai dengan panduan praktik terapi farmakologi dari Ikatan Apoteker Indonesia (IAI) (Pariang et al., 2020), dan standar protokol kesehatan dari Kementerian Kesehatan (Kementerian Kesehatan RI, 2021).

g) Melakukan pretest-posttest dengan kuesioner yang dibuat oleh penulis dan telah diuji validitas reliabilitasnya dengan hasil 10 pertanyaan valid dan nilai reliabilitas > 0.60 .

h) Membuat poster terapi farmakologi supaya menambah wawasan mitra yang mengalami gejala ringan dan (OTG) tanpa gejala.

i) Pemantauan dan evaluasi

Pemantauan kepatuhan terhadap pelaksanaan webinar terapi farmakologi Covid-19 pada pasien tanpa gejala dan gejala ringan. Satgas Covid-19 di Desa Cimekar tersebut membuat laporan kegiatan yang dilakukan pada akhir juli 2021. Untuk mengetahui pemahaman warga cimekar yang tanpa gejala, gejala ringan dan isoman 
JURNAL ASTA

Abdi Masyarakat Kita

Vol. 02 No. 01, Januari 2022

terhadap terapi farmakologi Covid-19 maka dilakukan posttest yang dilaksanakan pada akhir kegiatan ini yaitu pada tanggal 15 Agustus 2021.

\section{Deskripsi Perubahan yang Akan Terjadi di Masyarakat}

Perubahan perilaku terapi farmakologi Covid-19 pada warga Desa Cimekar yang telah memahami terapi apa saja yg dilakukan saat terpapar Covid-19 seperti mengkonsumsi vitamin C, E, D dan Zink dan dianalisis melalui hasil tes yang dilaksanakan di akhir kegiatan webinar pada program ini. Kegiatan ini dipublikasikan melalui media sosial KKN kelompok 31 yaitu youtube, instagram dan media massa sebagai media informasi yang dapat diakses oleh masyarakat terapi farmakologi Covid-19 pada warga tanpa gejala, gejala ringan dan isoman.

\section{Hasil dan Diskusi}

Penyesuaian Jadwal Kegiatan Bersama Mitra

Program penyelenggaraan penyuluhan secara daring ini akan dilaksanakan kepada masyarakat Desa Cimekar, Kecamatan Cileunyi. Kabupaten Bandung dengan menggunakan aplikasi zoom tema penyuluhan yaitu "Terapi Farmakologi Pada Pasien Covid-19 Orang Tanpa Gejala (OTG), Gejala Ringan dan Isoman" adalah salah satu upaya kontribusi civitas akademik Universitas Bhakti Kencana (UBK) Bandung terhadap masyarakat melalui pengabdian masyarakat yang dikoordinasi oleh PPM TEMATIK Universitas Bhakti Kencana Bandung. Kegiatan ini terselenggara bersama mitra yaitu warga Desa Cimekar Kecamatan Cileunyi Kabupaten Bandung.

\section{Pemberian Pretest}

Pretest sebagai kegiatan menguji/mengetahui tingkatan pengetahuan warga Desa Cimekar yang sedang melaksanakan isolasi mandiri terhadap materi yang akan disampaikan yaitu pengetahuan tentang "Terapi Farmakologi Pada Pasien Covid-19 Tanpa Gejala (OTG), Gejala Ringan dan Isoman". Pretes ini terdiri dari 10 (sepuluh) pertanyaan terkait penerapan 
terapi farmakologi pada pasien Covid-19 dan diikuti 106 orang. Skor yang diperoleh dari pretest adalah rentang 0-10 pada tabel berikut:

Tabel 1. Nilai-Rata Hasil Prettes Berdasarkan Kelompok Umur

\begin{tabular}{ccc}
\hline Kelompok Umur & Jumlah & Nilai Rata-Rata Pretest \\
\hline 17-20 Tahun & 79 & 7,96 \\
21-30 Tahun & 25 & 7,95 \\
>30 Tahun & 2 & 8 \\
\hline Total & 106 & $\mathbf{7 , 9 7}$ \\
\hline
\end{tabular}

Hasil pretest pada tabel 1 diketahui bahwa rata-rata pengetahuan terkait penerapan terapi farmakologi pada pasien Covid-19 yaitu 7.97. Nilai rata-rata terendah yaitu pada peserta kelompok umur 21-30 tahun dengan skor 7.95.

Nilai terendah yang diperoleh peserta kelompok umur 17-20 adalah 4 dan yang tertinggi 10 sehingga nilai rata-rata nya adalah 7,96, nilai terendah dari peserta kelompok umur 21-30 tahun adalah 5 dan nilai tertinggi 10 sehingga nilai rata-rata nya adalah 7,95 dan nilai terendah dari kelompok umur $>30$ tahun adalah 7 dan nilai tertinggi adalah 9 sehingga nilai rata-rata nya adalah 8 . Pada setia kelompok umur ada yang memahami penerapan terapi farmakologi Covid-19 dan ada juga yang belum memahami penerapan terapi farmakologi.

\section{Kegiatan Penyuluhan}

Perubahan perilaku untuk menangani permasalahan penularan Covid-19, yaitu dengan mendorong percepatan perubahan perilaku masyarakat agar secara konsisten menjalankan terapi farmakologi dengan mengkonsumsi vitamin C, E, D dan Zink. Perubahan perilaku manusia terjadi akibat dua dorongan, yakni dorongan dari dalam diri sendiri dan dorongan dari luar. Idealnya,perubahan perilaku berasal dari kesadaran dalam diri. Untuk menciptakan motivasi internal ini, akan dilakukan edukasi dan sosialisasi secara massif (BNPB, 2021). Orang yang memiliki cukup pengetahuan dan referensi literatur akan dapat mematuhi dan melaksanakan anjuran pemerintah dengan baik dan maksimal (Buana, 2021). 
Pada gambar 1, gambar 2, gambar 3 dan gambar 4 dapat dilihat proses kegiatan penyuluhan penerapan terapi farmakologi Covid-19 kepada mitra Desa Cimekar yang bertujuan untuk membangun pengetahuan mitra cara penerapan terapi farmakologi Covid19 kepada pasien isoman, Tanpa gejala dan Gejala Ringan. Penyuluhan dilakukan satu kali melalui media zoom meeting. Penyuluhan dilakukan pada hari minggu dengan kontra waktu mulai dari jam 08.00 pagi sampai 11.30 siang. Selama penyuluhan ada beberapa kegiatan, pemaparan materi tentang penerapan terapi farmakologi Covid-19 yang berisi, tanda gejala dari terpapar nya Covid-19, pengobatan dengan metode terapi dan kegiatan tanya jawab antara peserta dan narasumber.

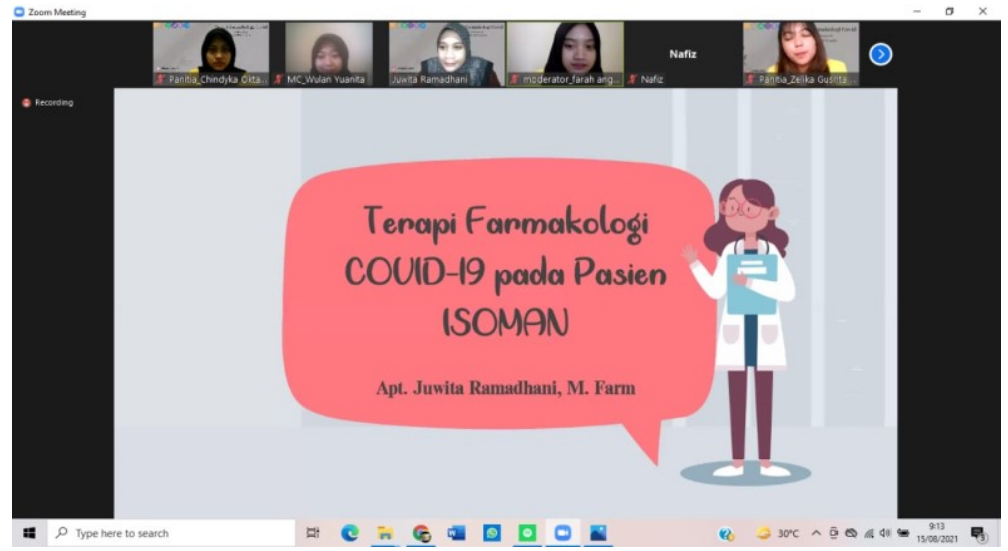

Gambar 1 Penyampain Edukasi Terapi Farmakologi Secara Online

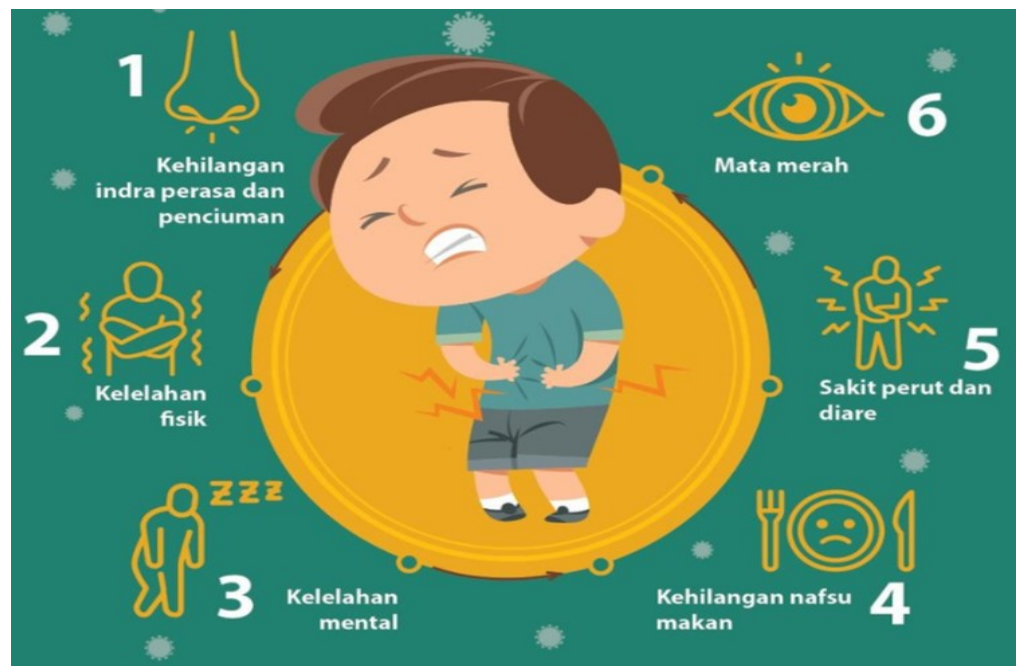

Gambar 2 Flyer Tanda dan Gejala Covid-19 

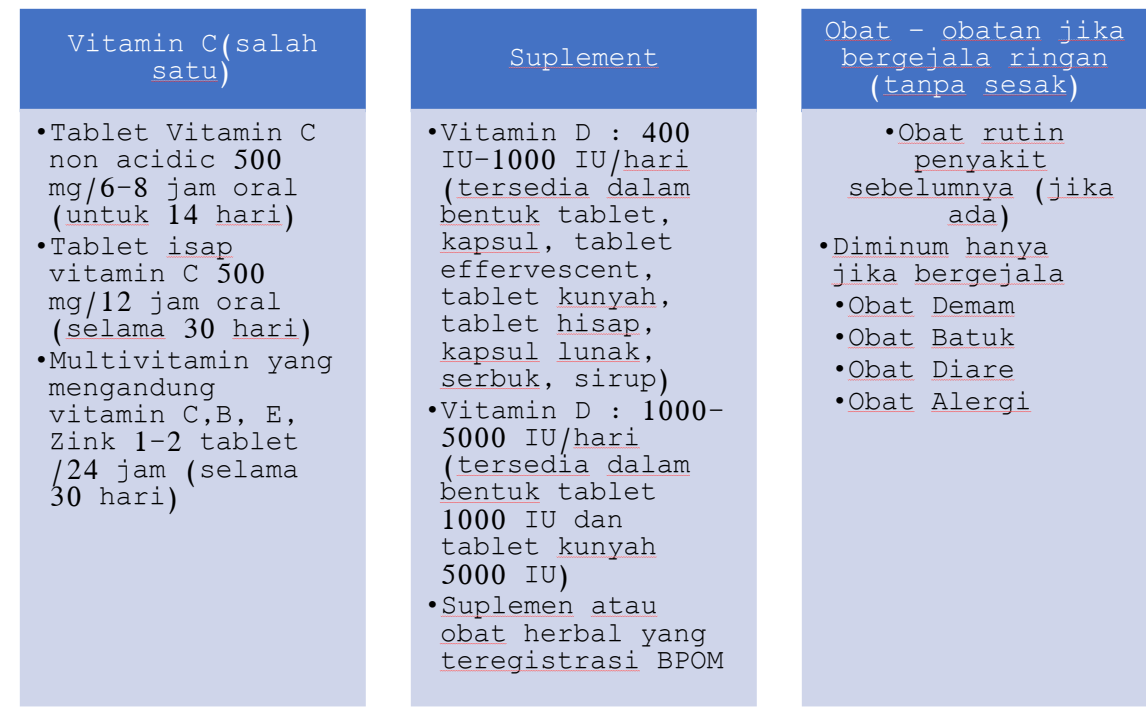

Gambar 3 Terapi Farmakologi yang di Sampaikan Kepada Peserta

\section{Pemantauan dan Evaluasi}

Pemantauan peserta dilihat dari hasil posttest yang dilakukan sesudah penyuluhan terapi farmakologi Covid-19. Tes dilakukan untuk mengetahui pengobatan terapi farmakologi Covid-19 terhadap pasien isoman, Tanpa Gejala dan Gejala Ringan. Tes terdiri dari 10 (sepuluh) pertanyaan dengan skor 0-10. Tes ini diikuti oleh 106 orang mitra Desa Cimekar. Skor posttest adalah pada tabel berikut:

Tabel 2. Perbandingan Nilai Pretest dan Posttest

\begin{tabular}{cccc}
\hline Kelompok Umur & Jumlah & $\begin{array}{c}\text { Nilai Rata-rata } \\
\text { Pretest }\end{array}$ & $\begin{array}{c}\text { Nilai rata-rata } \\
\text { Posttest }\end{array}$ \\
\hline 17-20 Tahun & 79 & 7,96 & 8,06 \\
21-30 Tahun & 25 & 7,95 & 8,12 \\
>30 Tahun & 2 & 8 & 8 \\
\hline Total & $\mathbf{1 0 6}$ & $\mathbf{7 , 9 7}$ & $\mathbf{8 , 0 6}$ \\
\hline
\end{tabular}

Covid-19 merupakan penyakit yang relatif baru dikenal masyarakat yaitu muncul di awal tahun 2020 sehingga sangat terbuka kemungkinan tidak semua masyarakat mengetahui dengan baik mengenai Covid-19 mulai dari faktor penyebab, proses transmisi sampai dengan 
upaya preventif dan upaya penanggulangannya, didasarkan kepada pemahaman tersebut maka sangat dibutuhkan edukasi yang dilakukan oleh Pemerintah Provinsi Jawa Barat bersama-sama dengan pemerintah kota/kabupaten yang ada di wilayah Provinsi Jawa Barat kepada masyarakat agar mereka mengetahui dengan baik tentang Covid-19 sehingga dengan pemahaman tersebut akan mendorong kesadaran dan sikap siap siaga terhadap penyebaran dan penanggulangan Covid-19 khususnya yang ada di lingkungan masyarakat

Pada tabel 2 rata-rata nilai pretest adalah 7,97 dan rata-rata untuk nilai posttest adalah 8,06 dimana nilai rata-rata posttest lebih besar menandakan adanya peningkatan pengetahuan tentang terapi farmakologi pada pasien Isolasi Mandiri. Hal ini juga berarti peningkatan pengetahuan didasari oleh penyuluhan melalui webinar.

\section{Deskripsi Perubahan yang Akan Terjadi di Masyarakat}

Kegiatan dapat menjadi sumber informasi yang mampu meningkatkan pengetahuan masyarakat tentang penerapan terapi farmakologi Covid-19 dengan tanpa gejala dan gejala ringan. Rangkaian kegiatan ini didokumentasikan dengan baik, dan telah di publikasikan melalui youtube pada tanggal 15 Agustus 2021 pukul 08.00 sampai 11.30; https://youtu.be/uPQoH17KR4s publikasi juga dilakukan melalui media massa yaitu koran pikiran rakyat Bandung yang telah di terbitkan pada 21 Agustus 2021: https://jabar.tribunnews.com/2021/08/21/terapi-farmakologi-covid-19-pada-pasien-isolasimandiri-orang-tanpa-gejala-otg-gejala-ringan

\section{Kesimpulan}

Penyuluhan penerapan terapi farmakologi Covid-19 di Desa Cimekar dapat meningkatkan pengetahuan cara penerapan terapi pada pasien Covid-19 dengan gejala ringan dan tanpa gejala. Hal ini diharapkan menjadi dorongan untuk perubahan perilaku masyarakat dalam penanganan Covid-19. Adapun rata-rata nilai pretest adalah 7,97 dan ratarata untuk nilai posttest adalah 8,06. 


\section{Ucapan Terimakasih}

Ucapan terimakasih kepada masyarakat Desa Cimekar, khsusnya satgas Covid-19 Desa Cimekar yang telah bersedia menjadi mitra dan bekerja sama dalam kegiatan Pengabdian kepada Masyarakat.

\section{Daftar Pustaka}

BNPB. Satuan Tugas Penanganan Covid-19. (2020). Pedoman Perubahan Prilaku

BNPB. Satuan Tugas Penanganan Covid 19. (2020). Jumlah Terpapar Covid-19 Di Indonesia Jakarta.

Davies, P. D. O. (2002). Multi-drug resistant tuberculosis. CPD Infection, 3(1), 9-12.

Pariang, N. F. E. et al. (2020) Panduan Praktis untuk Apoteker Menghadapi Covid-19. Jakarta: PT ISFI Penerbitan.

Rusdi, M. S. (2021) 'Mini Review: Farmakologi pada Corona Virus Disease (Covid-19)', Lumbung Farmasi ; Jurnal IImu Kefarmasian, 2(1), pp. 54-61.

Worldometers (2021) Covid-19 Coronavirus Pandemic, https://www.worldometers.info/. Available at: https://www.worldometers.info/coronavirus/country/indonesia/.

Davina, D. (2021) Meninggal Dunia Saat Isoman di Rumah, Sempat Sesak Napas dan Menolak Minum Obat, https://www.kompas.tv. Available at: https://www.kompas.tv/article/188908/meninggal-dunia-saat-isoman-di-rumahsempat-sesak-napas-dan-menolak-minum-obat.

Kementerian Kesehatan RI. (2021). Protokol Tatalaksana Covid-19 di Indonesia. Jakarata: Kementerian Kesehatan RI.

Pariang, N. F. E. et al. (2020) Panduan Praktis untuk Apoteker Menghadapi Covid-19. Jakarta: PT ISFI Penerbitan.

Worldometers (2021) Covid-19 Coronavirus Pandemic, https://www.worldometers.info/. Available at: https://www.worldometers.info/coronavirus/country/indonesia/. 